\title{
Reclamation of the Enugu Coal Mine Site at Abandonment
}

\author{
Amosu Cyril Olumuyiwa
}

\begin{abstract}
Mining of coal (fossil fuel) resources in Enugu resulted in groundwater pollution/depletion and left the mine site with the potentials of air pollution, loss of landscape/aesthetic degradation and soil contamination. Other Environmental impacts were extensive soil damage, alteration in microbial communities and affecting vegetation leading to destruction of vast amounts of land and displacement of dwellers. Reclamation is the process to restore the ecological integrity of these disturbed mine land areas. It includes the management of all types of physical, chemical and biological disturbances of soils such as soil $\mathrm{pH}$, fertility, microbial community and various soil nutrient cycles that makes the degraded land soil productive. Mining does not mean permanent loss of land for other use. On the other hand it holds potential for altered and improved use apart from restoring for agriculture, forestry and irrigation. This paper attempts to view the best practices for reclaiming the abandoned Enugu coal mine site which ceased production since 2002.
\end{abstract}

Keywords: Reclamation, Mining, Coal, Enugu, Soil, Production, Abandoned

\section{INTRODUCTION}

\section{Location and Geology of Enugu Coal Mine}

The Enugu coal mine is situated in Nigeria with the geographical position system (gps) coordinates of latitude and longitude of $6^{\circ} 27^{\prime} 35.8704^{\prime \prime} \mathrm{N}$ and $7^{\circ} 32^{\prime} 56.2164 " \mathrm{E}$. It has its Universal Transverse Mercator (UTM) for easting and northing as 339,535.91 and 714,279.07. Coal geology is a mixture of sedimentary rock and ancient vegetation which have been changed due to heat and microbial activities over considerable period of time (see figure $1-5$ ).

The first discovery of coal was in 1909, in Enugu, at the ridge of Udi. This was discovered by a British mine engineer called Albert Kitson. Coal extraction (figure 6) started with the Ogbete mine in 1916. The Enugu coal mine production attained about 183,012 tonnes in 1920 and about 574,758 tonnes in 1960 . However, production got crippled and abandoned in the mine due to the civil war which went on the $6^{\text {th }}$ of July, 1967 to $15^{\text {th }}$ of January, 1970. All efforts for revamping and recovery met a brick-wall. The major aim for the application of the Enugu coal is for the running of the Nigeria railway works.

Manuscript received on 8 October 2021 | Revised Manuscript received on 28 October 2021 | Manuscript Accepted on 15 November 2021 | Manuscript published on 30 November 2021. * Correspondence Author

Amosu Cyril Olumuyiwa*, Department of Mineral and Petroleum Engineering, Yaba College of Technology, Yaba. Email: cyril.amosu@yabatech.edu.ng

(c) The Authors. Published by Lattice Science Publication (LSP). This is an open access article under the CC-BY-NC-ND license (http://creativecommons.org/licenses/by-nc-nd/4.0/)

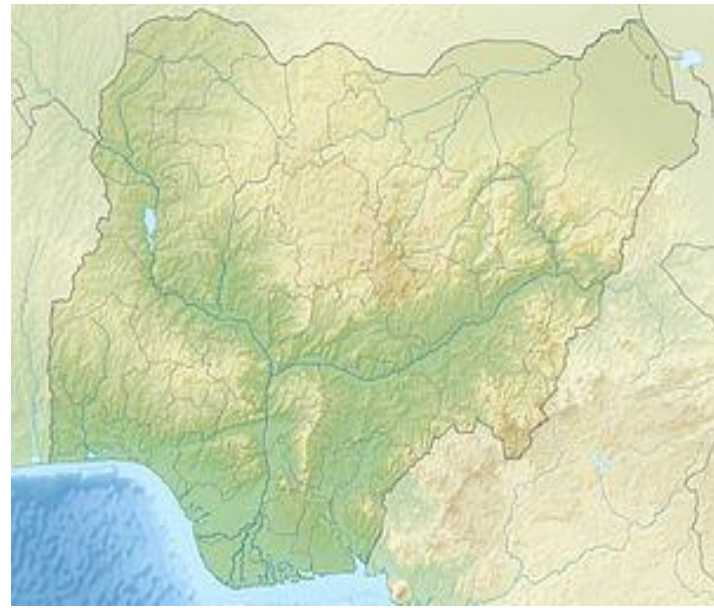

Figure 1: Locational Map

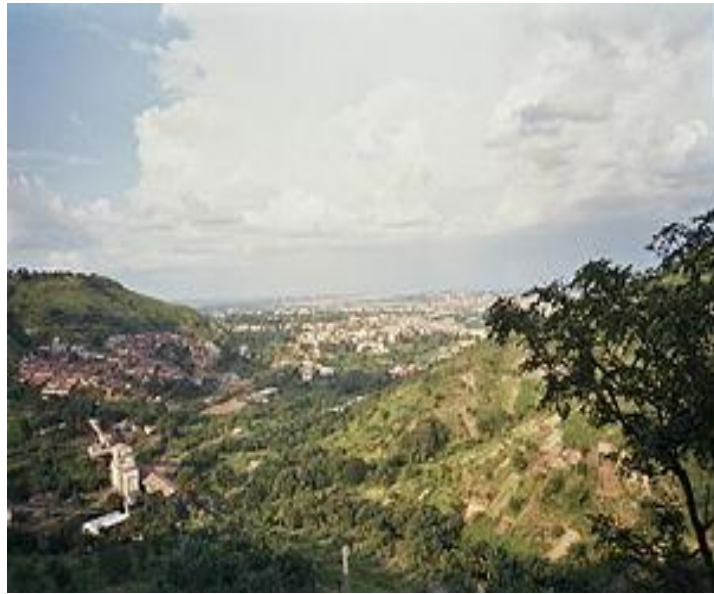

Figure 2: Enugu from the west

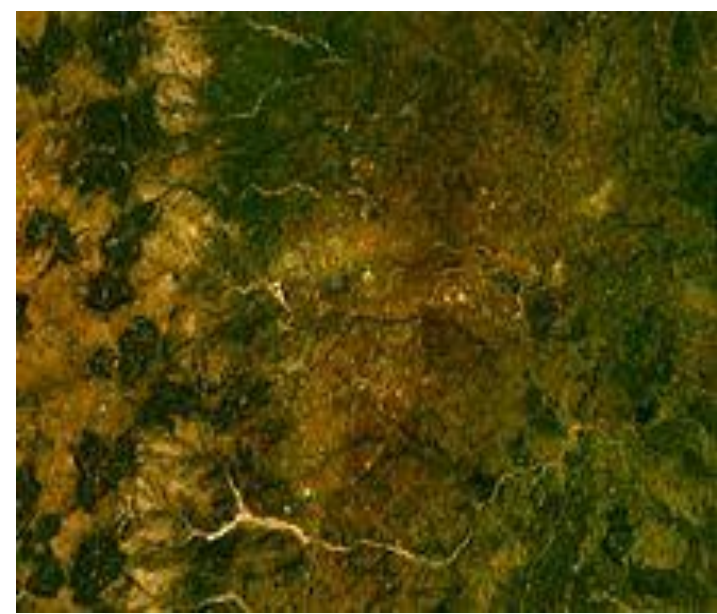

Figure 3: Satellite image of Nigeria Enugu Escarpment

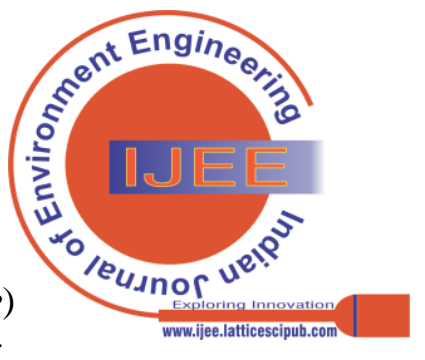




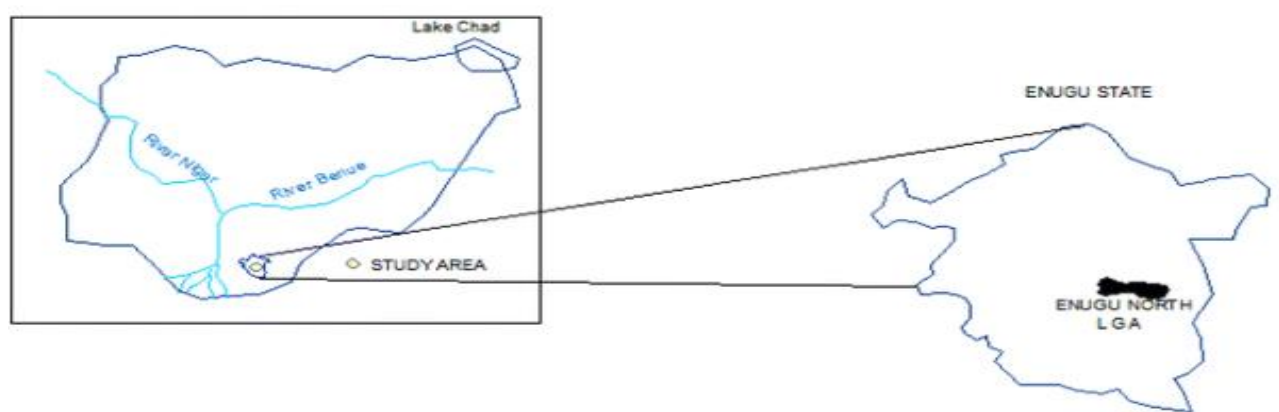

Figure 4: Study Area: Map of Enugu Coal Mine in Nigeria

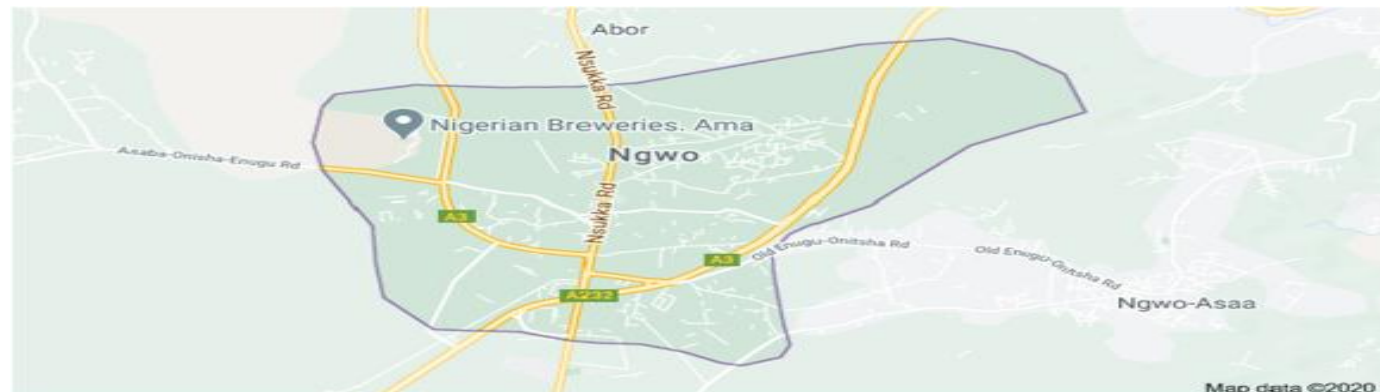

Figure 5: Enugu Coal Mine Enugu in Nigeria (sciencedirect.com)

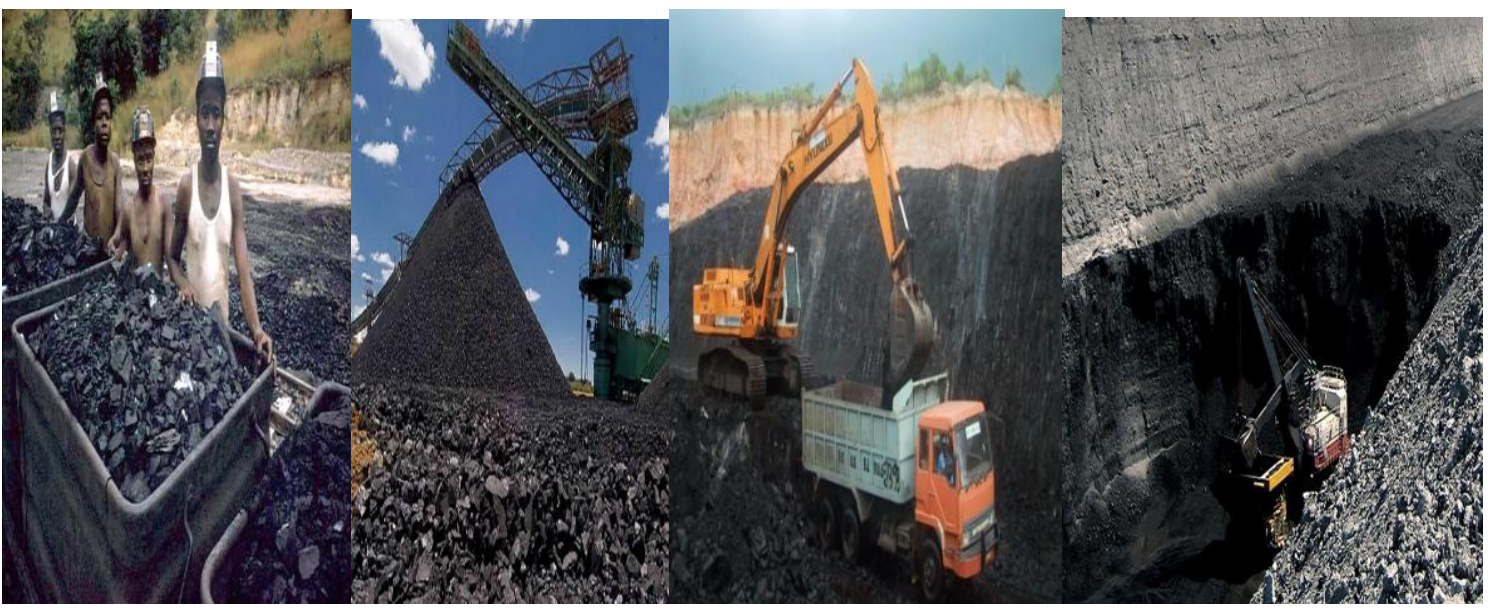

Figure 6: Enugu Ekulu Coal Mine (ejatlas.org; engineersforum.com.ng; mosaicmanagementltd.com and grassroot.ng)

Mine Site Remediation Issues

1. Soil:
Apart from landscape damage, the operations of mining create sands that are laden with heavy metals that have mixed with the parental soils which eventually contaminates land areas and water bodies (see Figure 7).

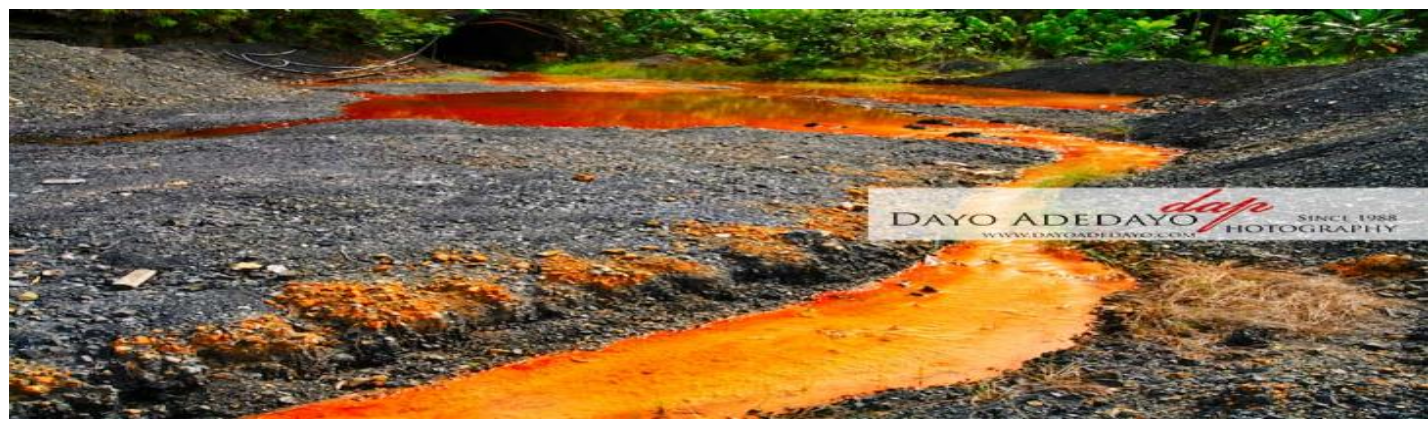

Figure 7: Acid Mine Drainage in Enugu coal mine causing Water and Soil Contamination (dayoadedayo.com)

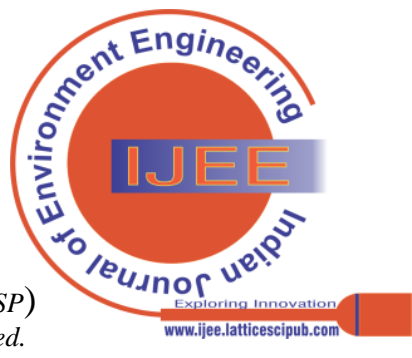




\section{Water:}

a) The main sources of pollution associated with mining is acid mine drainage (AMD) (see Figure 7) caused by pyrite (especially exposed iron sulphide) which reacts with the water and oxygen, forming sulphuric acids and dissolving iron which later precipitates (yellow, orange or yellow sediments) down to aquifers sources (surface and ground water) which invariably causes harm to man, wildlife and the environment (Ezemokwe and Madubuike,2015)

WHO (2011) also made report of a total dissolved solids (TDS) values that range between $21.80 \mathrm{mg} / \mathrm{l}$ and $520 \mathrm{mg} / \mathrm{l}$ that were below their permissible limits of $0.00-1500 \mathrm{mg} / \mathrm{l}$ even though these may still be hazardous to the aquatic ecosystem in the location (WHO, 2011).

b) Slurry tailings that are dumped into water or close to it contaminates it through leaching which leads to death of aquatic life and hazards to the ecosystem.

\section{Air Quality:}

Fugitive dust increases the particulate matter (PM) in the composition of the air around the location of mine which when inhaled causes serious respiration hazard.

\section{Reclamation Solutions}

\section{Revegetation and Reforestation:}

Plants (Grasses, trees, etc.) which can inhabit animals are cleared and relocated under the supervision and instruction of professionals and properly saved for future reclamation, ever before mining operation commences.

The nature of soil to relocate should possess microbes like bacteria so as to provide the necessary nutrients for the growth of plant. Such microbes include Agrobacterium rhizogenes, Pseudomonas fluorescens, Ectomycorrhizal fungi and rhizosphere bacteria. The fixing of fungi and bacteria at the same time gives correct and significant effect, and prevents behaviour of opposition (Krummelbein and others, 2012). For best results, the following process is adopted:

The selection of plants/crop should be based locational adequacy and behaviour for advancing the productivity of neighbourhood soil, according to the following conditions which are viewed as advantageous to make available new ecosystem for fauna and flora, to hold water, retain carbon dioxide and profit the weather (Logters, 2004):

i. Minimal applications of fertiliser to the soils dumped initially

ii. Remains of plants and its root proceeds.

iii. High application of dumped substrates that has potential production

iv. Minimal necessity for storage of water;

v. Inherent penetration and crop's root absorption potentials

The choice of cultured species is normally advised when revegetating. Afforestation is embraced to return the area of mining into an environment enveloped with trees. The Forestry Reclamation Approach (FRA) has imbibed a new step to afforestation for surfaced mines that are alreadt abandoned which are viewed in five ways (Sullivan and Amacher, 2010):

establishing an adequate plant root system suitable better growth;

- $\quad$ redressing the topsoil in a loose manner; improvement;

- $\quad$ planting valuable crops and trees that are viable, on time

- $\quad$ applying the best tree techniques of planting.

\section{Soil Amendments:}

Topsoils will be reusedn after being removed and stockpiled initially; but where the topsoil does not exists, new soil is needed which must be compatible with the environment. Deeper soils from the minesites can be combined with top soils (NSE, 2009). Vigorous revegetation is advised to appropriate new growth of the roots of crops into the soils for a long period mostly when the weather is wet, (Krummelbein and others, 2012). Soil analysis should be carried out at different stages of mining in order to assess it before mining begins and at the time of revegetation armed with adequate knowledge of the concepts applied and the unknown connected with samples (Hursthouse 2012). For these soils to become reusable, they will go through the restoration process, of which mine spoils does not possess nitrogen, carbon and phosphorus (Tripathi and Singh, 2008). Also low or acidic $\mathrm{pH}$ should be remediated by applying lime or ash for good return of plant growth (Bian and others, 2010; Krummelbein and others, 2012).). In all of these, the best suggested depths is not more than $100 \mathrm{~cm}$. The quantity of the fertiliser and its type required to improve the topsoil relies on the state of the covering soil on the minesite and its anticipated use (i.e. forestry or to agricultural). Sewage sludge and other organic residues can be used to improve the structure of the soil and its water-retaining propensity.

\section{Water Drainage:}

This is benefitial as a function of local geo-topography. Here, stones are applied to water drainage canals in order to avert loss of water and erosion of soil (Jason, 2015).

\section{Refill and Ground Surface Reshaping:}

Once mining is complete in a specific area at the mine, active reclamation begins, even as other parts of the mine are in operation. The first step is to refill the ground with gangue and reshape the surface, according to the specifications set in the original mining permits, and determined based on the original terrain (Jason H., 2015).

Reclamation and Rehabilitation: Statutory Provisions, As Per MCDR, 1988

\section{1) As Per Section 23 - Abandonment of Mines:}

a) The owner of mines, contracted mining engineer, or mine manager of every mine shall communicate to the Regional Controller, Mine Controller, Controller General, with specific notice to get to them within ninety days when abandonment comes to play.

b) This specific notice shall be followed-up with sectional plans on any suitable scale.

c) The manager, mine owner, mining engineer and agents in mines are not to abandon a mine fully or in part.

d) Unless a final mine closure is reached, he leaseholder is not advised to abandon any portion of the mine

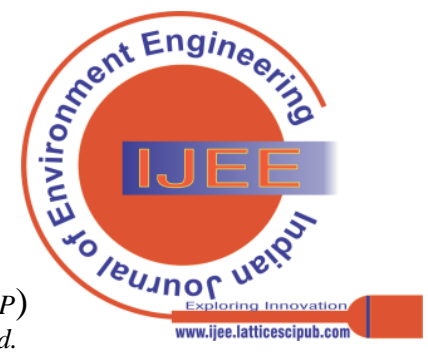


e) The authorized officer on board kicks against any form of abandonment; and if it he chooses to , it has to be on his own terms and conditions.

2) As Per Section 34 - Reclamation And Rehabilitation Of Lands:

Phased restoration, rehabilitation and reclamation of abandoned mines shall be carried out by holders of licences or by those who vie for mining lease or license during mining operations before final abandonement of mine (Sauvick M. and Krishna K., 2016).

\section{LITERATURE REVIEW}

The most critical processes in the ecosystem development include colonization by appropriate selected species, accumulation of nutrients both in plants and soils, changes in soil structure and reduction in toxicity, these critical processes lead to distinct and characteristic flora (Bradshaw, 1983; Hington and Lindman, 1987). Successful biological reclamation restores the natural capital of biota and productivity of land, which have been previously destroyed by mining operations (Sheoran and Poonia, 2010). If preserved surface soil layer is going to be used in agricultural reclamation, Ličina et al. (2017) suggest a prior metal assessment as a component of a future rehabilitation policy for topsoil in food and fodder production (Ličina et al, 2017). According to Miletić (2004), one of the main limiting factor for the growth and development of the forest trees on the reclaimed mine soils in mining basin is the lack of nitrogen (Miletić 2004). Previous studies have shown that bioremediation uses biological agents such as fungi, bacteria, and green plants (phytoremediation) to remove, mineralize or neutralize hazardous substances in soil (Adetitun et al, 2018; Akande et al, 2018 and Abbaslou and Bakhtiari 2017). Previous studies have revealed that wastewater use for irrigation and waste disposal on the soil results in heavy metal accumulation in soils and bioaccumulation in plants beyond maximum permissible limits for both humans and livestock consumption (Alam et al, 2018; Karbassi et al,2014 and Ghaderi, 2012). The
Reclamation for forestry is decided by the topography or terrain, and the soil property (Simmons, 2008). The approach of gangue filling reclamation technology is appropriate for all kinds of mining areas (Miao and Zhang, 2007). Switchgrass has been used in reclamation studies on roadsides (Skousen and Venable, 2008), surface mines (Skeel and Gibson, 1996; Marra and Skousen, 2012; Dere et al., 2011), sand and gravel mines (Gaffney and Dickerson, 1987), lignite overburden (Skousen and Call, 1987), and lead and zinc mines (Levy et al., 1999; Skousen, and Venable. 2008; Skeel, and Gibson, 1996; Dere, Stehouwer, and McDonald. 2011; Gaffney and Dickerson. 1987; Skousen and Call,1987; Levy, Redente and Uphoff. 1999). Ore deposits are often associated with arsenic, lead, mercury and other toxic metals which often find their way into the air, water and food chains once they are released from underground rock formations during mining (Amosu, Enitan and Eniola, 2021).

\section{MATERIAL AND METHODOLOGY}

\section{Data Collection}

Table 1: The Nigerian Coal Corporation - A Production Performance Evaluation from 1960-1987.

\begin{tabular}{|c|c|}
\hline \multicolumn{2}{|c|}{ Production Levels } \\
\hline Years & Tonnes Produced \\
\hline 1916 & 25,511 \\
\hline 1920 & 180,122 \\
\hline 1930 & 347,115 \\
\hline 1940 & 318,594 \\
\hline 1950 & 583,425 \\
\hline 1960 & 565,681 \\
\hline 1970 & 24,404 \\
\hline 1980 & 118,317 \\
\hline 1987 & 117,159 \\
\hline EQUATION & $\mathrm{y}=-323.6 \mathrm{x}^{2}+1 \mathrm{E}+06 \mathrm{x}-$ \\
& $1 \mathrm{E}+09$ \\
\hline $\mathbf{R}^{2}$ & $\mathrm{R}^{2}=0.578$ \\
\hline
\end{tabular}

Quantitative Economic Research Bureau (Godwin, 2008).

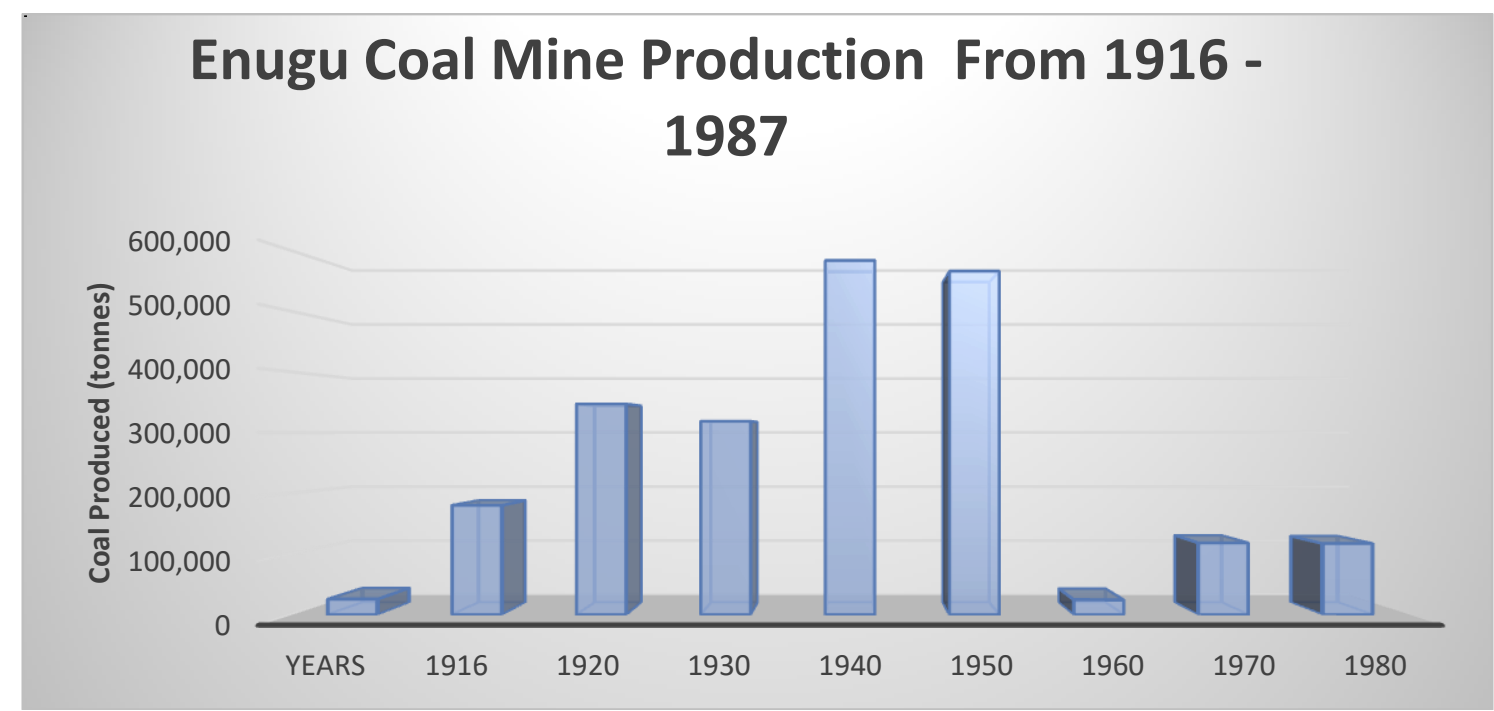

Figure 8: Annual Production capacity of coal in Enugu Coal Mine.

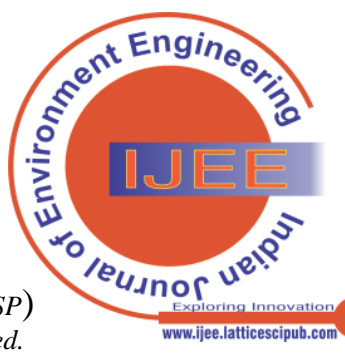


Table 2: Analysis and report of Ezemokwe and Madubuike, 2015 showing the quality of water in two mine zones situated in Enugu (i.e. Onyema and Okpala) in which he discovered the mean values of some heavy metals as $5.5 \mathrm{mg} / \mathrm{l}$.

\begin{tabular}{|c|c|}
\hline Heavy Metals & Metallic Concentrations (mg/l) \\
\hline Cadmium & 0.33 \\
\hline Arsenic & 0.06 \\
\hline Lead & 0.53 \\
\hline Chromium & 0.06 \\
\hline Mean Value & $\mathbf{5 . 4}$ \\
\hline
\end{tabular}

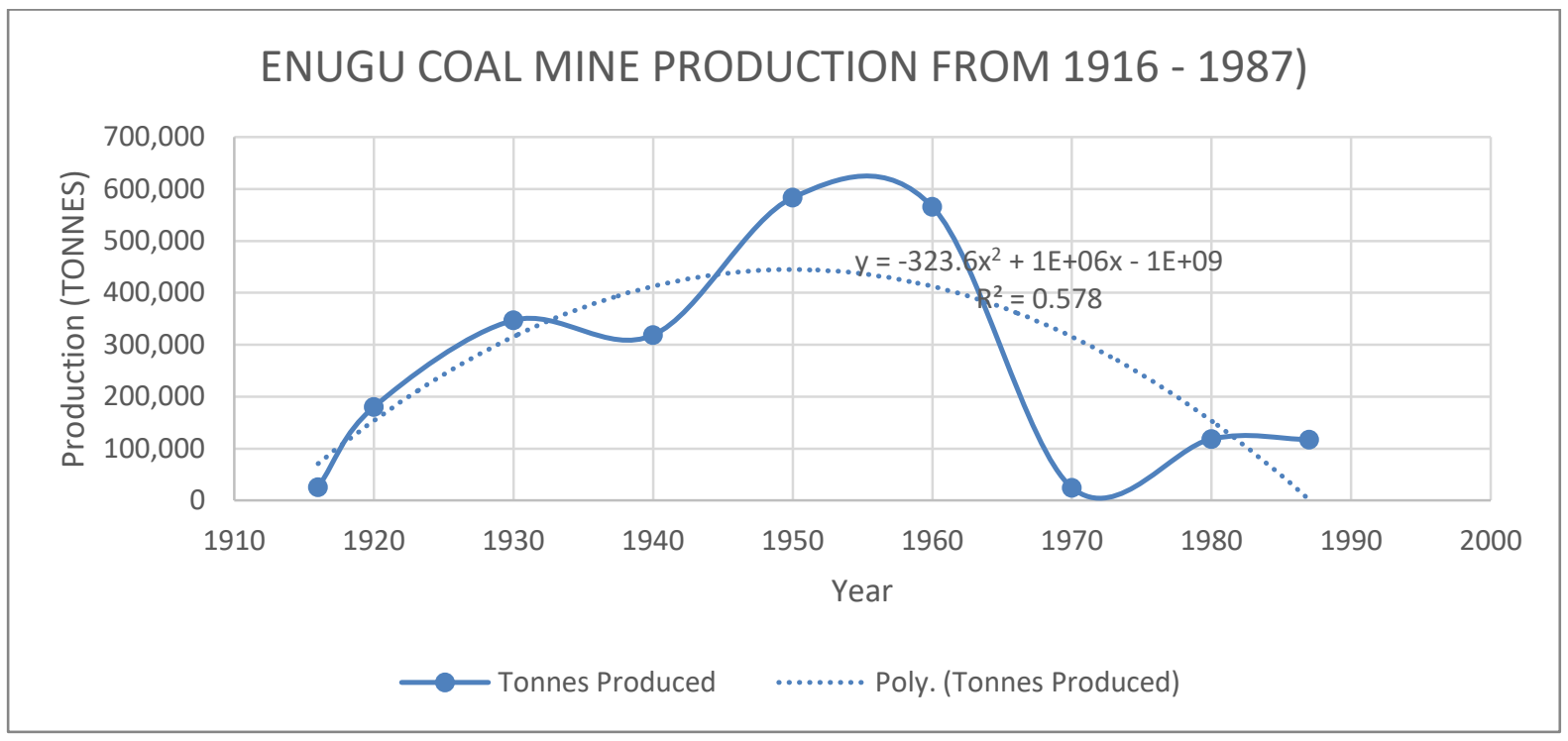

Figure 9: Straight line plot for the annual production capacity of coal in Enugu Coal Mine.

This exceeds the permissible limits of the World Health Organization (WHO) of 0.0-5.0mg/l for all identified metals (WHO, 2011).

\section{THE QUALITY OF WATER ON TWO COAL MINES IN ENUGU}

$$
\text { Metallic Concentrations (mg/l) }
$$

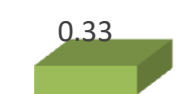

Cadmium

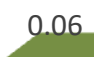

Arsenic

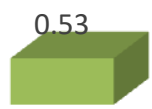

Lead

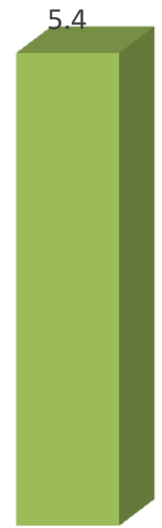

Mean Value

Figure 10: Metallic Contamination of the quality of water after production is carried out in the Enugu Coal Mine.

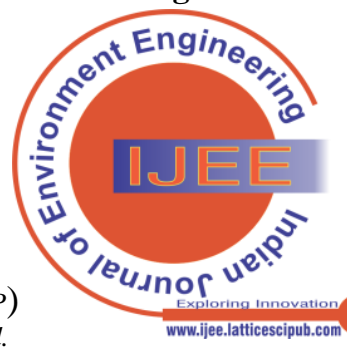




\section{Data Review and Analysis}

Considering Figure 8, as compiled by Godwin, 2008, the production capacity for coal kicked-started sweetly at a high production rate of 25,511 tonnes per year in 1916. This rose continuously until a peak of 583,425 tonnes was produced in 1950. Production however declined the next year by about $3 \%$, in 1960. It picked up again with high hopes to 118,317 tonnes which it maintained with a little rise later, but which also dropped at the close of 1987 by another $0.9 \%$.

Figure 9 confirms the certainty in data of production that was discussed previously; using the polynomial order, the correlation was calculated as $\mathrm{R}^{2}$ equals to 0.578 showing there is almost average chance of either an advance or decline in coal production rate on the Enugu Coal Mine.

Using Figure 10, compiled by Ezemokwe and Madubuike, 2015; it is evident that the metallic concentrations in the Enugu Coal Mine is getting alarming since it exceeded the permitted mean threshold for the hazardous metallic compounds found on it.

\section{RESULTS AND DISCUSSION}

The production on the Enugu Coal Mine declined at the tail-end of production year in 1987. Even though it had the potential for future production, it got abandoned possibly due to the high value of hazardous concentrations of metals that came with its coal production.

\section{CONCLUSION AND RECOMMENDATION}

The program of reclamation is essential after mining activities is terminated in a minesite, for sufficient restoration and return to original state. There are many alternatives for this process of restoration of land integrity. Government should assist for funding through revenues, levies and other supports. Legal acts should be promulgated and permission to work or get licence/lease should be adequately put in place to check mining operations before and after it commences.

\section{REFERENCES}

1. Abbaslou H. and Bakhtiari S. (2017) : Phytoremediation potential of heavy metals by two native pasture plants (Eucalyptusgrandis andailanthusaltissima) assisted with AMF and fibrous minerals in contaminatedminingregions; Pollution,vol.3,no.3,pp.471-486.

2. Adetitun D., Akinmayowa V., Atolani O., and Olayemi A. (2018): Bio degradation of jet fuel by three Gram negative Bacilli isolated from kerosene contaminated soil," Pollution,vol.4,no. 2,pp.291-303.

3. Akande F., Ogunkunle C., and Ajayi S. (2018): Contamination from petroleum products - Impact on soil seed banks around an oil storage facility in Ibadadan, South-West Nigeria,'Pollution,vol.4, no. 3, pp. 515-525.

4. Alam A.R.,.Hossain A.B.M, Hoque S.,and.Chowdhury D.A (2018): Heavy metals in wetland soil of Greater Dhaka District, Bangladesh; Pollution,vol.4,no.1,pp.129-141.

5. Ali S. (2014): Mining and the Environment: What Happens When A Mine Closes?

6. Amosu C.O., Enitan C.S.A. and Eniola C.S.A. (2021): Implication of Mining to Health in Maiganga Coal Mine, Gombe State, Nigeria ; Department of Mineral and Petroleum Engineering Yaba College of Technology, Yaba; Indian Journal of Management and Language (IJML), Volume-1 Issue-2. [CrossRef]

7. Andisiwe S. (2012): An Assessment of Abandoned Mine Reclamation in South Africa Using A Survey of Environmental Experts; A thesis submitted in partial fulfilment of the Requirements for the Master of Science degree, Department of Microbiology, University of Fort Harare.

8. Bian X, Inyang H I, Daniels J L, Otto F, Struthers S (2010): Environmental issues from coal mining and their solutions. Mining Science and Technology; 20 (2); 215-223. [CrossRef]

9. Bradshaw A.D. (1983): The reconstruction of ecosystems; J. Appl. Ecol.; 20: 1-17. [CrossRef]

10. Dere A.L., Stehouwer R.C. and McDonald K.E. (2011): Nutrient leaching and switchgrass growth in mine soil columns amended with poultry manure. Soil Science 176:84-90. [CrossRef]

11. Ezemokwe D.E. and Madubuike P.C. (2015): Impact of Coal Mining in Enugu Area of Nigeria on the Surrounding Water Quality; IOSR Journal of Environmental Science, Toxicology and food Technology; Vol 9, No. 12, Pp. 35-45.

12. Gaffney F.B. and Dickerson J.A. (1987): Species selection for revegetating sand and gravel mines in the northeast. J. Soil Water Conserv. 42:358-361.

13. Ghaderi A.A., Abduli M.A.,.Karbassi A.R, asrabadi T.N, and M. Khajeh (2012): Evaluating the effects of fertilizers on bioavailable metallic pollution of soils, case study of sistan farms, Iran," International Journal of Environmental Research,vol.6,no.2, pp. 565570 .

14. Godwin Chukwudum Nwaobi (2008): The Nigerian Coal Corporation - An Evaluation of Production Performance (1960 1987); Quantitative Economic Research Bureau.

15. Hington MJ,and L indman N.(1987): Environmental impacts of coal mining and utilization. Pergamon, Oxford,. p.332.

16. Hursthouse A (2012): Assessing background concentrations of priority substances. Environmental Scientist; 21 (3); 9-15.

17. Jason H. (2015): Returning Mined Land to Productivity Through Reclamation. Vol. 3, Issue 4, The official journal of The World Coal Industry,

18. Karbassi A.,.Nasrabadi T,.Rezai M,and.Modabberi S (2014): Pollution with metals (As, Sb, Hg, Zn) in agricultural soil located close to zarshuran gold mine, Iran; Environmental Engineering and Management Journal,vol.13,no.1,pp.115-120. [CrossRef]

19. Krummelbein J, Bens O, Raab T, Naeth M A (2012): A history of lignite coal mining and reclamation practices in Lusatia, eastern Germany. Canadian Journal of Soil Science; 92 (1); 53-66. [CrossRef]

20. Levy D.B., Redente E.F. and Uphoff G.D. (1999): Evaluating the phytotoxicity of pb-zn tailings to big bluestem (Andropogon gerardii Vitman) and switchgrass (Panicum virgatum L.); Soil Sci. 164:363375. [CrossRef]

21. Lesley S. (2013): Coal Mine Site Reclamation. Technical Report.

22. Ličina, V., Fotirić Akšić, M., Tomić, Z, Trajković, I., Antić Mladenović, S., Marjanović,M., Rinklebe, J. (2017): Bioassessment of heavy metals in the surface soil layer of an opencast mine aimed for its rehabilitation, Journal of Environmental Management, 186, p. 240-252. [CrossRef]

23. Logters C (2004): Recultivation of opencast mines - perspectives for the people living in the Rheneland. World of Mining -Surface and Underground; 56 (2); 126-135.

24. Marra, M, and J. Skousen. (2012): Switchgrass potential on reclaimed surface mines for biofuel production in West Virginia. In: Proceedings, American Soc. Mining and Reclamation, Tupelo, MS, 8-15. [CrossRef]

25. Miao X.X. and Zhang J.X. (2007): Analysis of strata behavior in the Process of coal mining by gangue backfilling, Journal of Mining Safety Engineering,vol.45,no.5,pp.618-627.

26. Miletić, Z. (2004): Soil development in landfills of REIK Kolubara under influence of forest plantations [in Serbian], PhD Thesis, University of Belgrade, Faculty of Forestry, Belgrade.

27. NSE, Nova Scotia Environment (2009): Guide for surface coal mine reclamation plans; Environmental Assessment Branch, Nova Scotia Environment, Canada.

28. Reclamation of Abandoned Mining Sites (2006): Some ExamplesMERN Inspecting and environmental monitoring.

29. Sauvick M. And Krishna K. (2016): Remediation of mined out areas and abandoned Mines-A case study on Sesa's Approach1.

30. Sheoran, V., Sheoran, A., Poonia,P (2010): Soil reclamation of abandoned mine land by revegetation: a review, International Journal of Soil, Sediment and Water, 3, p. 2-13.

31. Skeel, V.A. and D.J. Gibson (1996): Physiological performance of Andropogon gerardii, Panicum virgatum, and Sorghastrum nutans on reclaimed mine spoil; Restor. Ecol. 4:355-367. [CrossRef]

32. Skousen, J.G. and C.L. Venable (2008): Establishing native plants on newly-constructed and older-reclaimed sites along West Virginia highways [electronic resource]. Land Degrad. Dev. 19:388-396. [CrossRef]

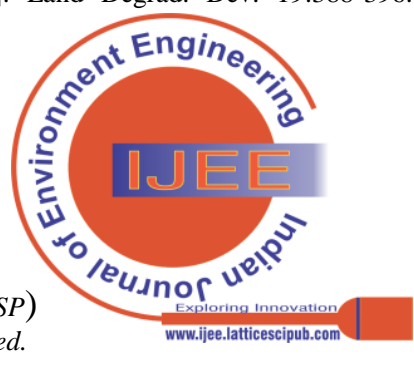


33. Skousen, J.G. and Call C.A. (1987): Grass and forb species for revegetation of mixed soil-lignite overburden in east central Texas; J. Soil Water Conserv. 42:438-442.

34. Simmons J. A., Currie W. S. and Eshleman K. N. (2008): Forest to reclaimed mine land use change leads to altered ecosystem structure and function; Ecological Applications,vol.18,no.1, pp. 104-118.

35. Sullivan J. and Amacher G. S. (2010): Private and social costs of surface mine reforestation performance and criteria. Environmental Management; 45; 311-319. [CrossRef]

36. Tripathi N. and Shekkar S. R (2008): Ecological restoration of mined-out areas of dry tropical environment, India. Environmental Monitoring and Assessment; 146; 325-337. [CrossRef]

37. WHO (2011): Publications on Water sanitation and health

38. Wustenhagen D, Kendzia G, Dahnert D (2009): Mining and agriculture - cooperation in the Lusatian mining area. World of Mining - Surface and Underground; 61 (5); 300-307.

\section{AUTHORS PROFILE}

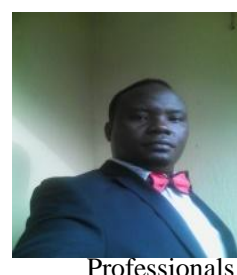

\section{MINING ENGINEER}

\section{AMOSU CYRIL OLUMUYIWA}

Professional background:

- Lecturer and researcher at Yaba College of Technology, Lagos, Nigeria.

$$
\text { - Associate Environmental }
$$
Professionals (AEP), National registry Of Environmental Professionals (NREP).

\section{Education:}

- Council for Regulation of Engineering In Nigeria (COREN).

- $\quad$ Master of Engineering (M. Eng.) in Mining Engineering from Federal University of Technology Akure, Nigeria (2019 - Date).

- Masters (M. Sc.) in Petroleum Engineering and Project Development (2004 - 2005).

- $\quad$ Bachelors of Engineering (B. Eng.) in Mining Engineering from Federal University of Technology Akure, Nigeria (1995 - 2001).

Previous publishing experience

About ten (10) journals published already with different publishers which can be found on Google Scholar, ResearchGate, Publon and Orcid. These journals captures Mining and Petroleum.

Personal details:

Married with three (3) children; lives in Lagos state, Nigeria; Personal interest is writing and research.

\section{Contact information:}

Personal E-mail: muyixx1zillion@gmail.com

Official E-mail: Cyril.amosu@yabatech.edu.ng

Phone Number: +2348036302750; +2348021910353

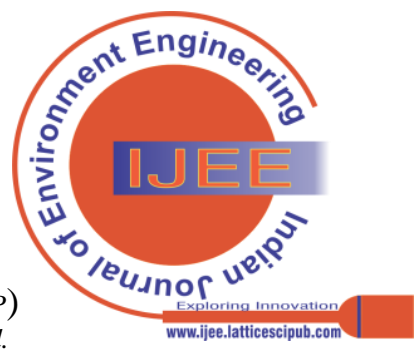

